change in the relative incidence of meningococcal and influenzal infections during the period of the survey.

Presenting symptoms and signs are discussed, and the frequency of the combination of fever, irritability, and vomiting is noted. The high incidence of fits is stressed. Cerebrospinal fluid abnormalities are discussed.

A basic plan of treatment has been evolved, with modifications according to the bacteriological findings.

All of these points are considered separately for neonatal meningitis and the diagnostic difficulties are discussed.
We would like to acknowledge the contribution of the medical and nursing staffs of Sunderland Children's Hospital and the Havelock Infectious Diseases Hospital, Sunderland, in the care of these cases. We thank Mrs. B. D. Eldridge for secretarial assistance.

\section{REFERENCES}

Brit. med. 7., 1961, 2, 226.

Esrachowitz, S. R. (1961). S. Afr. med. 7., 35, 281.

Heycock, J. B. (1959). Brit. med. f., 1, 629.

- and Noble, T. C. (1962). Ibid., 2, 879

Shaw, E. B., and Bruyn, H. B. (1960), 7. Pediat., 56, 253.

Veghelyi, P. V. (1962). Ibid., 60, 122.

\title{
Adrenocortical Function in Chronic Malnutrition
}

\author{
J. N. C. COOKE, ${ }^{*}$ † O.B.E., M.D., M.R.C.P. ; V. H. T. JAMES, † PH.D. \\ J. LANDON,§ M.B. ; V. WYNN,§ M.D.
}

Brit. med. F., 1964, 1, 662-666

On clinical grounds there may be difficulty in differentiating a variety of chronic wasting diseases from Addison's disease or hypopituitarism. The differential diagnosis is made more difficult by the finding that in chronic maltnutrition, as in pituitary or adrenal hypofunction, there may be hyponatraemia, an impaired ability to excrete a water load, and undue insulin sensitivity and hypoglycaemic unresponsiveness (Emanuel, 1956 ; Shuster, 1957 ; Nabarro et al., 1957). The urinary excretion of steroids by debilitated subjects may be decreased (Prunty, 1956 ; Bliss and Migeon, 1957) and their response to corticotrophin (A.C.T.H.) may be impaired (Birke et al., 1960), which suggests that all these effects are due to direct or indirect impairment of adrenal function.

The present investigation concerns the effects of chronic malnutrition upon the pituitary adrenal axis and attempts to elucidate some of the mechanisms involved. A further object of the study was to test the validity of using convalescenthospital patients as a control group by comparing their results with those obtained in healthy volunteers.

\section{Material}

A total of 129 adult subjects (61 men and 68 women) were studied. They were divided into three groups in each sex categorized as follows:

Group 1.-This comprised 35 male and 33 female healthy volunteers who were normally nourished and who had had no recent illness or operation.

Group 2.-This comprised 11 male and 17 female hospital in-patients under investigation, or convalescent after various illnesses. They were of near average weight and in no case was this more than $10 \%$ below the expected average for their sex, height, and age. It was considered that these patients would probably correspond to those used as control subjects by most previous investigators.

Group 3.-This comprised 15 male and 18 female patients who were severely wasted owing to a variety of chronic illnesses, and who were under investigation and treatment in a metabolic ward. Their body weights ranged from 20 to $40 \%$ below the expected average

$\star$ Royal Air Force Hospital, Wroughton, Wilts.

t Now at Royal Air Force Hospital, Aden.

\$ Department of Chemical Pathology, St. Mary's Hospital Medical School London.

$\checkmark$ Surgical Unit, St. Mary's Hospital, London. for their sex, height, and age. Of the 33 patients, 11 had panmalabsorption due to a variety of causes, 4 had ulcerative colitis, 6 had rheumatoid arthropathy, 6 had anorexia nervosa, 3 had chronic tubercle involving lungs or bone, 2 had carcinoma, and 1 had a benign oesophageal stricture. None of these patients suffered from an acute infection or had had a recent surgical operation at the time of study. No patient had known endocrine disease or significant reduction in renal function, or had been receiving glucocorticoids.

Because of difficulties in admitting group 1 subjects to hospital our data are incomplete for this group.

\section{Methods}

The following tests were carried out:

1. Estimation of the 24-hour resting urinary excretion of 17-ketosteroids (17-KS) and 17-hydroxycorticosteroids (17OHCS). Wherever possible a minimum of two 24-hour urine collections were obtained and preserved under toluene $(10 \mathrm{ml}$.) at $4^{\circ} \mathrm{C}$. Urinary $17-\mathrm{KS}$ were estimated by the method of Drekter et al. (1952) and 17-OHCS as described by Appleby et al. (1955) modified to include periodate oxidation (Few, 1961). In both methods the colorimetry was modified by the use of ether extraction (James and de Jong, 1961).

2. Measurement of the response of urinary steroid excretion to the intramuscular injection of A.C.T.H. gel ("acthar") 60 i.u. 12-hourly for three days.

3. The determination of the resting plasma-cortisol level in blood samples taken between 9.30 and 10.30 a.m. The plasma cortisol was determined fluorometrically by the method of de Moor et al. (1960) modified as described by James et al. (1962).

4. The plasma-cortisol response to insulin-induced hypoglycaemia (Landon et al., 1963).

5. The determination of the half-life of exogenous cortisol by the method of Brown et al. (1954).

\section{Results}

\section{Urinary Steroid Excretion}

Table 1 compares the mean 24-hour urinary excretion of $17-\mathrm{KS}$ and 17-OHCS in the three different groups of male and female subjects. 
TABLE I.-Mean 24-Hour Urinary Excretion of Steroids (17-KS and $17-O H C S)$

\begin{tabular}{|c|c|c|c|c|c|c|c|c|}
\hline \multirow{2}{*}{ Group } & \multirow{2}{*}{ Sex } & \multirow{2}{*}{$\begin{array}{l}\text { No. of } \\
\text { Subjects }\end{array}$} & \multicolumn{2}{|c|}{$\begin{array}{c}17-\mathrm{KS} \\
\text { (mg./24 hr.) }\end{array}$} & \multicolumn{2}{|c|}{$\begin{array}{l}\text { 17-OHCS } \\
\text { (mg./24 hr.) }\end{array}$} & \multicolumn{2}{|c|}{$\begin{array}{c}\text { 17-KS/17-OHCS } \\
\text { Ratio }\end{array}$} \\
\hline & & & Mean & S.D. & Mean & S.D. & Mean & S.D. \\
\hline $\begin{array}{l}1 \\
2 \\
3 \\
1 \\
2 \\
3\end{array}$ & $\begin{array}{c}M \\
M \\
M \\
\mathbf{F} \\
\mathbf{F} \\
\mathbf{F}\end{array}$ & $\begin{array}{l}35 \\
11 \\
15 \\
33 \\
17 \\
18\end{array}$ & $\begin{array}{r}11 \cdot 0 \\
10.6 \\
4.9 \\
8 \cdot 1 \\
7.5 \\
3.7\end{array}$ & $\begin{array}{l}2.80 \\
2.75 \\
1.59 \\
2.93 \\
2.65 \\
1.63\end{array}$ & $\begin{array}{r}14 \cdot 2 \\
14 \cdot 9 \\
13 \cdot 0 \\
10 \cdot 1 \\
11 \cdot 9 \\
9 \cdot 2\end{array}$ & $\begin{array}{l}3.07 \\
3.19 \\
3.70 \\
2.33 \\
3.27 \\
2.61\end{array}$ & $\begin{array}{l}0.78 \\
0.73 \\
0.39 \\
0.75 \\
0.65 \\
0.40\end{array}$ & $\begin{array}{l}0.17 \\
0.18 \\
0.12 \\
0.11 \\
0.21 \\
0.14\end{array}$ \\
\hline
\end{tabular}

There was no significant difference in the mean urinary 17-KS excretion between group 1 and group 2 subjects of either sex. However, both male and female group 3 subjects had a significantly lowered $17-\mathrm{KS}$ excretion $(\mathrm{P}<0.001)$. For example, the mean urinary excretion of $17-\mathrm{KS}$ was $11.0 \mathrm{mg}$./ 24 hours in group $1 \mathrm{men}$, and $8.1 \mathrm{mg}$. $/ 24$ hours in group 1 women, compared with values of 4.9 and $3.7 \mathrm{mg} . / 24$ hours in group 3 men and women respectively.

In contrast to these findings there was no significant difference in the mean urinary excretion of 17-OHCS between group 1 and group 2 or group 3 men and women. This difference between the effects of chronic ill-health and malnutrition on the excretion of $17-\mathrm{KS}$ and 17 OHCS is reflected in their ratio in the various groups. Thus the $17-\mathrm{KS} / 17-\mathrm{OHCS}$ ratios for group 1 men and women were 0.78 and 0.75 respectively, while the values in group 3 men and women were significantly lower $(P<0.001)$, being 0.39 and 0.40 .

\section{Urinary Steroid Response to Intramuscular A.C.T.H.}

The means and standard deviations for the urinary $17-\mathrm{KS}$ and 17-OHCS response to a three-day course of A.C.T.H. (60 i.u. b.d.) are shown in Table II and Fig. 1.

The group 1 male controls showed a significantly higher response $(0.01>\mathrm{P}>0.001)$ on all three days of A.C.T.H.

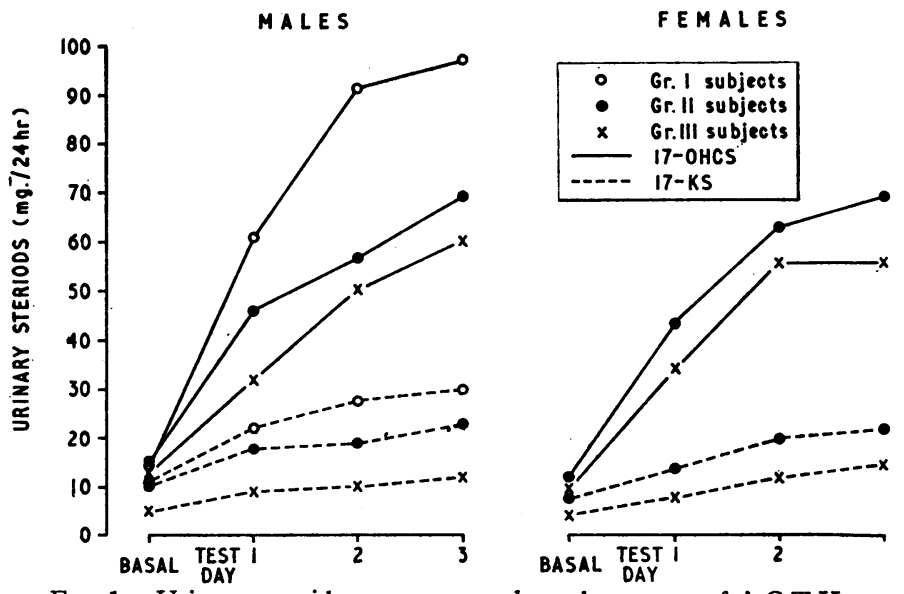

FIG. 1.-Urinary steroid response to a three-day course of A.C.T.H. administration, for both urinary fractions, compared with any of the other groups. As an approximation these subjects doubled their basal 17-KS excretion and quadrupled their 17-OHCS excretion in the first 24 hours. Further significant increments occurred on the second day of the test, but by the third day the increases were only small. This last observation was true for all the other groups.

Group 2 men and women produced mean responses to A.C.T.H. in both 17-KS and 17-OHCS which were significantly less $(0.01>P>0.001)$ than those observed in the group 1 men. There was no significant difference in response between group 2 men and women with the exception that the first day $17-\mathrm{KS}$ increment was lower than in the female group.

Group 3 patients showed no sex differences in their mean A.C.T.H. response. Their $17-\mathrm{KS}$ responses were significantly lower on all three days of A.C.T.H. administration than those of group $2(P<0.001)$ and consequently were much lower than those of group $1(P<0.001)$. Their $17-O H C S$ responses also showed lower mean values than group 1 or group 2 , being significantly different from group $1(P<0.001)$ on all three days of the test. Compared with group 2 there was a significant difference only on the first day of A.C.T.H. $(P<0.01)$. On the second and third days of A.C.T.H. administration large standard deviations from the group 3 mean values are apparent. This reflects our finding that while nearly all group 3 subjects showed an impaired response on the first day of A.C.T.H., the responses on the second and third days were very variable, ranging from continued marked impairment in about one-third of the cases to near normal responses in others.

\section{Resting Plasma-Cortisol Levels}

The plasma-cortisol data obtained from men and women have been combined, since they showed no significant sex differences. Resting plasma-cortisol values were compared for group 2 and group 3 male and female subjects (see Table III). The mean plasma-cortisol level for 23 group 2 patients $(9.3 \pm$ $2.8 \mu \mathrm{g} . / 100 \mathrm{ml}$.) was identical to that found in 19 group 3 patients $(9.3 \pm 3.2 \mu \mathrm{g} . / 100 \mathrm{ml}$.).

TABLE III.-Resting Plasma-Cortisol Levels in Group 2 and Group 3

\begin{tabular}{|c|c|c|c|c|c|}
\hline & & & & & \\
\hline \multirow{2}{*}{ Group } & \multirow{2}{*}{$\underset{\text { Patients }}{\text { No. of }}$} & \multirow{2}{*}{$\begin{array}{c}\text { No. of } \\
\text { Determina- } \\
\text { tions }\end{array}$} & \multicolumn{3}{|c|}{ Plasma Cortisol $(\mu \mathrm{g} . / 100 \mathrm{ml})}$. \\
\hline & & & Mean & S.D. & Range \\
\hline $\begin{array}{l}2 \\
3\end{array}$ & $\begin{array}{l}23 \\
19\end{array}$ & $\begin{array}{l}50 \\
45\end{array}$ & $\begin{array}{l}9 \cdot 3 \\
9 \cdot 3\end{array}$ & $\begin{array}{l}2 \cdot 8 \\
3.2\end{array}$ & $\begin{array}{l}5 \cdot 9-15 \cdot 0 \\
5 \cdot 9-17 \cdot 4\end{array}$ \\
\hline
\end{tabular}

\section{Plasma-Cortisol Response to Insulin-induced Hypoglycaemia}

This test was used to measure the integrity of the hypothalamic-pituitary-adrenal axis and the ability of this system to respond to stress. Table IV shows the comparative results of the blood-sugar and plasma-cortisol levels in nine group 3

TABLE II.-Changes in Urinary Steroid Excretion (17-KS and 17-OHCS) after A.C.T.H. Stimulation*

\begin{tabular}{|c|c|c|c|c|c|c|c|c|c|c|c|}
\hline \multirow[b]{2}{*}{ Group } & \multirow[b]{2}{*}{ Sex } & \multirow{2}{*}{$\begin{array}{c}\text { No. } \\
\text { of } \\
\text { Subjects }\end{array}$} & & \multicolumn{4}{|c|}{ 17-KS (mg./24 hr.) } & \multicolumn{4}{|c|}{ 17-OHCS (mg./24 hr.) } \\
\hline & & & & $\begin{array}{c}\text { Mean } \\
\text { Resting } \\
\text { Value }\end{array}$ & 1st Day & 2nd Day & 3rd Day & $\begin{array}{c}\text { Mean } \\
\text { Resting } \\
\text { Value }\end{array}$ & 1st Day & 2nd Day & 3rd Day \\
\hline 2 & $\mathbf{M}$ & \{ & $\begin{array}{l}\text { Mean } \\
\text { S.D. }\end{array}$ & $\begin{array}{c}10 \cdot 6 \\
2 \cdot 75\end{array}$ & $\begin{array}{c}17 \cdot 7 \\
4 \cdot 70\end{array}$ & $\begin{array}{c}18 \cdot 8 \\
4 \cdot 33\end{array}$ & $\begin{array}{c}22 \cdot 3 \\
5 \cdot 70\end{array}$ & $\begin{array}{c}14 \cdot 9 \\
3 \cdot 19\end{array}$ & $\begin{array}{l}45.9 \\
11.69\end{array}$ & $\begin{array}{c}56 \cdot 1 \\
9 \cdot 45\end{array}$ & $\begin{array}{l}69 \cdot 0 \\
13.34\end{array}$ \\
\hline 3 & $\mathbf{M}$ & 14 & $\begin{array}{l}\text { Mean } \\
\text { S.D. }\end{array}$ & $\begin{array}{l}4.9 \\
1.59\end{array}$ & $\begin{array}{l}8 \cdot 5 \\
4 \cdot 13\end{array}$ & $\begin{array}{c}10 \cdot 0 \\
4.80\end{array}$ & $\begin{array}{c}11.7 \\
5.01\end{array}$ & $\begin{array}{c}13 \cdot 0 \\
3.70\end{array}$ & $\begin{array}{l}31 \cdot 7 \\
13 \cdot 17\end{array}$ & $\begin{array}{l}49 \cdot 9 \\
23 \cdot 45\end{array}$ & $\begin{array}{l}59 \cdot 4 \\
25 \cdot 46\end{array}$ \\
\hline
\end{tabular}

- A.C.T.H. gel (60 i.u. b.d.) was given by intramuscular injection for three days. 
TABLE IV.-Plasma-cortisol Response to Insulin-induced Hypoglycaemia

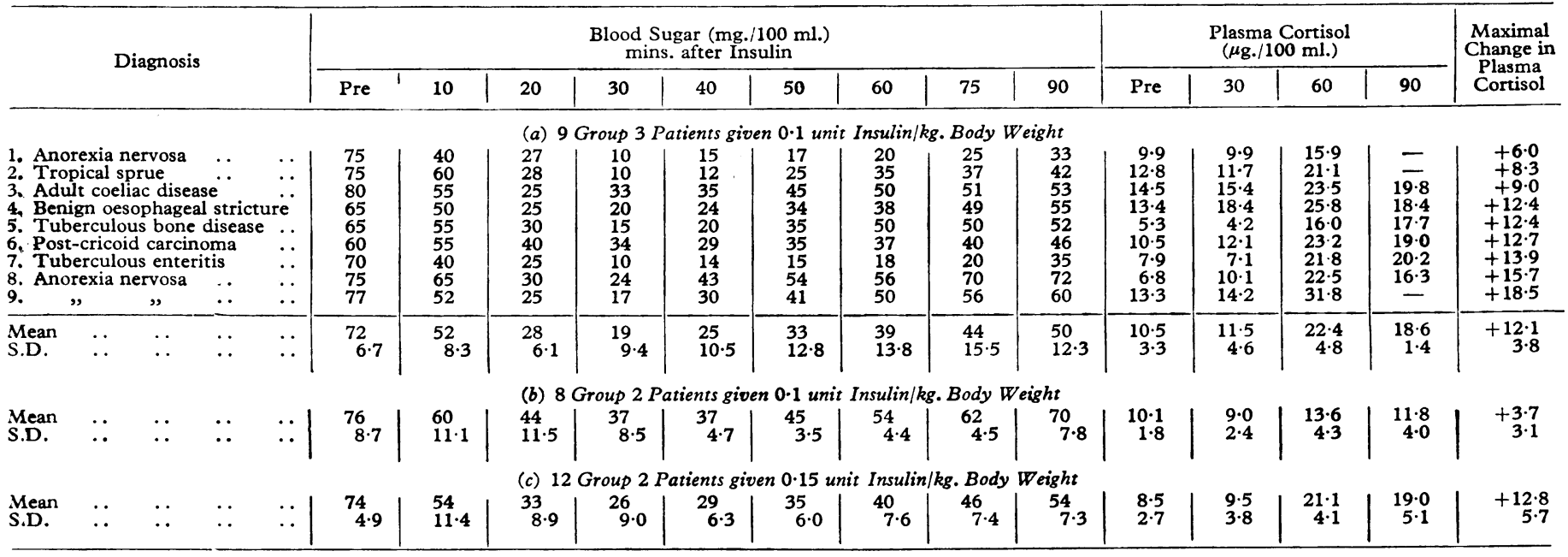

and eight group 2 subjects given 0.1 unit of insulin per kilogram body weight. It also shows the mean blood-sugar and plasmacortisol response to 0.15 unit of insulin $/ \mathrm{kg}$. body weight given to a further 12 group 2 patients.

The wasted group 3 patients were insulin-sensitive and showed hypoglycaemic unresponsiveness as compared with group 2 subjects. Thus the mean blood-sugar levels in group 3 patients fell by about $70 \%$ of the fasting level at the end of 30 minutes as compared with $50 \%$ for group 2 patients, and had regained the fasting value only at 90 minutes in one patient. These differences were significant $(P<0.01)$. The lowest blood-sugar concentrations in group 3 patients lay in the range 10 to 29 $\mathrm{mg} . / 100 \mathrm{ml}$. and this degree of hypoglycaemia was associated in all cases with a significant increase in plasma cortisol ranging from 6 to 18.5 , with a mean increase of $12.1 \mu \mathrm{g} . / 100 \mathrm{ml}$. This rise in plasma cortisol was significantly greater $(P<0.001)$ than the mean increase of only $3.7 \mu \mathrm{g} . / 100 \mathrm{ml}$. observed in group 2 subjects given the same dose of insulin. However, the group 2 blood-sugar values fell only to about $40 \mathrm{mg} . / 100 \mathrm{ml}$. When the degree and duration of hypoglycaemia observed in group 3 patients was reproduced in group 2 patients by giving a larger dose of insulin ( $0.15 \mathrm{unit} / \mathrm{kg}$. body weight) the mean rise in plasma cortisol of $12.8 \mu \mathrm{g} . / 100 \mathrm{ml}$. was not significantly different from that found in the group 3 patients.

\section{Half-life of Exogenous Cortisol}

Studies were made in 11 group 2 and 13 group 3 patients of both sexes. The results are summarized in Table $V$ and shown in more detail in Fig. 2. In group 2 subjects the mean cortisol half-life was 92 minutes and all the values lay within the accepted normal range of 70 and 120 minutes. In the studies carried out in chronically ill group 3 patients the mean cortisol half-life was 136 minutes, a value which is significantly
Table V.-Cortisol Half-life in Group 2 and Group 3 Patients

\begin{tabular}{c|c|c|c|c}
\hline \multirow{2}{*}{ Group } & \multirow{2}{*}{$\begin{array}{c}\text { No. of } \\
\end{array}$} & \multicolumn{3}{|c}{ Cortisol Half-life (Minutes) } \\
\cline { 2 - 4 } & & Mean & S.D. & Range \\
\hline 2 & 11 & 92 & $12 \cdot 8$ & $75-120$ \\
3 & 13 & 136 & $29 \cdot 5$ & $80-189$ \\
\hline
\end{tabular}

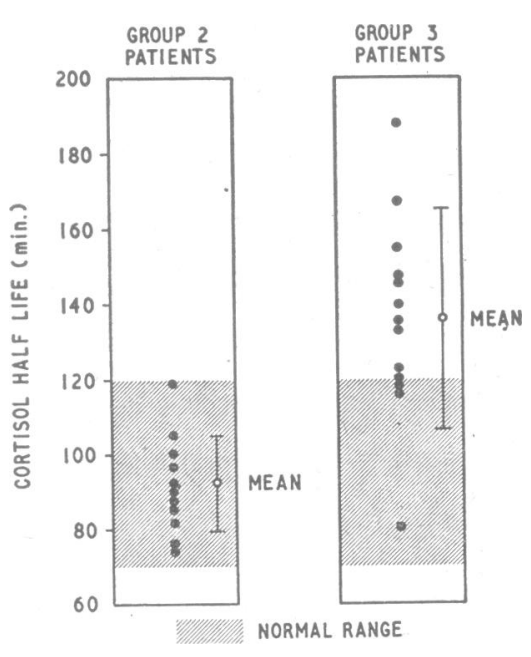

Fig. 2.- Half-life of infused cortisol in

11 Group 2 and 13 Group 3 Patients.

higher than that found in group 2 subjects $(P<0.001)$. In 12 of these group 3 studies the cortisol half-life was near or above the upper limit of normal. The single exception was a cachectic woman with tuberculous enteritis who had a normal cortisol half-life, which was confirmed on two occasions.

TABLE VI.-Effects of Treatment on Adrenal Function Tests in some Group 3 Patients

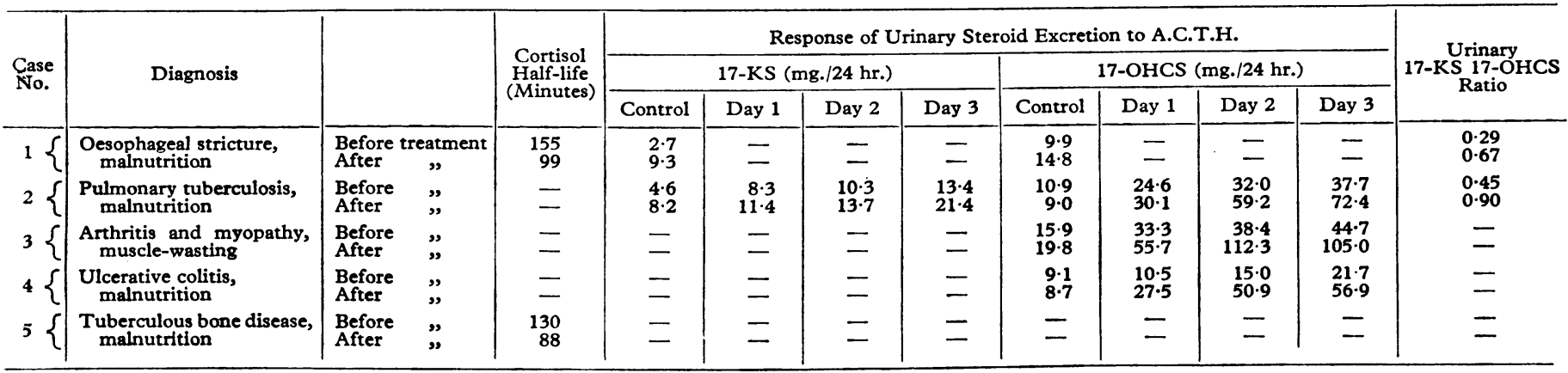




\section{Studies on Group 3 Patients Before and After Treatment}

In five group 3 patients it was possible to repeat some of the tests after their health and nutritional state had improved with treatment. These results, given in Table VI, show that therapy has been associated with an improvement, the results after treatment approximating to the mean values obtained in group 2 subjects.

Thus in Case 1, a 74-year-old severely wasted woman with an oesophageal stricture (body weight $36 \mathrm{~kg}$.), the mean urinary excretion of $17-\mathrm{KS}$ was 2.7 and of $17-\mathrm{OHCS} 9.9 \mathrm{mg} . / 24$ hours, giving a 17-KS/17-OHCS ratio of 0.29 . After her weight had increased by $5 \mathrm{~kg}$. in response to treatment, her mean urinary excretion of $17-\mathrm{KS}$ and $17-\mathrm{OHCS}$ had risen to 9.3 and $14.8 \mathrm{mg} . / 24$ hours respectively, giving a ratio of 0.67 . These changes were associated with a fall in the cortisol half-life from 155 to 99 minutes.

In case 2 a man admitted with pulmonary tuberculosis and malnutrition also showed a definite rise in his mean 17-KS excretion and a consequent rise in his $17-\mathrm{KS} / 17-\mathrm{OHCS}$ ratio, with treatment. This was associated with a marked improvement in his urinary $17-\mathrm{KS}$ and 17-OHCS response to A.C.T.H. Cases 3 and 4 showed a similar improvement in their 17-OHCS response to A.C.T.H., the maximal rise being more than doubled after therapy. Finally Case 5 showed a fall in her cortisol halflife from 130 to a mean value of 88 minutes after treatment.

Restoration of normal body weight was not essential, since a definite improvement occurred soon after the patients went into a strongly anabolic phase as measured by metabolic balance studies.

\section{Discussion}

The purpose of the present investigation was to study adrenocortical function in relation to chronic illness and malnutrition. In common with many other investigations of this type, it has been necessary to assess the observations made in relation to control data. Since it is impractical in most cases to obtain such data from a normal healthy population, it is common practice to study as control subjects convalescent patients or patients with conditions which are considered to be "nonendocrine." Our observations on such patients as compared with normal healthy subjects would suggest that these two groups are not entirely similar as regards some aspects of adrenocortical function; thus, although basal urinary steroid excretion was not significantly different in the two groups, the response of the urinary $17-\mathrm{KS}$ and $17-\mathrm{OHCS}$ to A.C.T.H. was considerably lower in the hospital patients. The selection of "control" subjects for investigations of this nature clearly requires care, since a variety of conditions may in fact cause deviations in metabolism of a sufficient magnitude to warrant consideration.

In the present study, chronically ill malnourished patients showed several abnormalities of adrenocortical function. These included a low 24-hour urinary excretion of 17-KS, an impaired urinary 17-KS and 17-OHCS response to A.C.T.H., and a delayed rate of disappearance of cortisol from the plasma. The urinary excretion of 17-OHCS was not, however, significantly low as compared with control subjects, and both the resting plasma-cortisol level and the adrenocortical response to acute hypoglycaemic stress were normal.

Many previous investigations have shown that starvation and wasting conditions reduce the urinary excretion of 17-KS (Emanuel, 1956; Bliss and Migeon, 1957; Albeaux-Fernet et al., 1957 ; Shuster, 1957) ; even a four-day period of starvation may cause a $50 \%$ reduction in $17-\mathrm{KS}$ excretion in normal subjects (Landau et al., 1948). Some previous authors have also suggested that malnutrition may lower the urinary excretion of 17-OHCS (Bliss and Migeon, 1957; Huseby et al., 1959 ; Shuster, 1960). However, Denneberg and Skanse (1958) found no significant difference in 17-OHCS excretion between control subjects and debilitated patients, and Birke et al. (1960) reported variable results in a similar investigation.

We have found no significant effect of chronic malnutrition on the urinary excretion of 17-OHCS, in contrast to the marked decrease in 17-KS excretion, and there was a consequent lowering of the $17-\mathrm{KS} / 17-\mathrm{OHCS}$ ratio. This selective reduction of 17-KS excretion has been observed previously in old age and in leukaemia (Gallagher, 1957), and has been interpreted as a conservation of glucocorticoid production, while the less vital components of adrenocortical secretion, the adrenal androgens, are not so maintained. Such a process is apparently a common feature of many diseases and may relate essentially to nutritional status.

The A.C.T.H. stimulation studies reported in this investigation showed significantly lower 17-KS and 17-OHCS responses in severely malnourished patients as compared with the control subjects. The increased response consequent upon nutritional improvement seemed to suggest that malnutrition was the major factor responsible for the differences. While there is general agreement that chronic wasting illness is associated with a poor $17-\mathrm{KS}$ response to A.C.T.H. (Nabarro, 1961), there does not seem to have been the same recognition that the urinary 17-OHCS response to A.C.T.H. may also be impaired in malnutrition, although Birke et al. (1960) reported similar findings in some wasted patients.

Despite the inability of the chronically malnourished patients to respond normally to a three-day course of A.C.T.H., they showed a prompt plasma-cortisol response to a hypoglycaemic stress which was indistinguishable from that observed in hospital "control" patients. While we have not studied the response of the plasma cortisol to exogenous as opposed to endogenous A.C.T.H., there is ample evidence from other studies that similar patients show a normal response (Eik-Nes et al., 1955 ; Sandberg et al., 1956 ; Christy et al., 1957 ; Shuster, 1960). These findings indicate that the hypothalamicpituitary-adrenal axis must be intact (Landon et al., 1963) and that the wasted individual is still capable of a normal shortterm response to stress.

In the present investigation, using a relatively specific method, the chronically malnourished patients were found to have a mean plasma-cortisol value identical with that of a group of hospital "control" patients, the individual values falling within our normal range for healthy subjects. Other investigators (Bliss and Migeon, 1957 ; Shuster, 1960) have reported high plasma-cortisol values in chronically ill and wasted patients. However, they employed non-specific methods for determining the plasma cortisol, which may also measure cortisol metabolites and other compounds. It must be emphasized that all the wasted patients studied in the present investigation were in a relatively stable chronic phase of their illness, since acute illness and the terminal stages of any disease may be associated with profound changes in steroid metabolism and very high plasmacortisol values (Sandberg et al., 1956 ; Hume et al., 1956 ; Helmreich et al., 1957).

The rate of disappearance of infused cortisol was delayed in 12 out of 13 chronically wasted patients. We have found no reference, in previous studies, to this effect of chronic malnutrition, but Mills (1962) reported that the cortisol half-life is prolonged in normal subjects by a four-day fast.

From the foregoing observations it appears that general malnutrition is associated with considerable changes in steroid metabolism. These changes are complex and are not capable of full explanation on the present available evidence. It seems clear from our findings that the vital requirements for an adequate plasma-cortisol level and the capability for its elevation in response to acute stress remain unimpaired. At the same time it seems likely that less essential functions, such as the provision of androgens, are selectively depressed, and, as judged by the quantitative response to A.C.T.H., the adrenocortical reserve is reduced. 
It remains to consider how chronic ill-health and malnutrition may produce their effects on steroid metabolism. The prolonged cortisol half-life found in wasted patients indicates a delayed hepatic catabolism, since the liver is the main site of cortisol breakdown (Tomizawa et al., 1954). Liver disease which produces a prolonged cortisol half-life is not associated with a delayed dihydrocortisone removal rate (Peterson, 1960) and a limited number of studies have shown that malnutrition also does not delay dihydrocortisone metabolism (unpublished observations). This indicates that the abnormality of cortisol catabolism involves the initial reduction of cortisol to dihydrocortisol and hence the $\Delta 4$ reductase system. The activity of this enzyme system has in fact been shown to decrease significantly in the livers of fasting rats (Herbst et al., 1960), possibly owing to a decrease in reduced niacin adenine dinucleotide phosphate, which is the essential hydrogen donor for the system.

A prolonged cortisol half-life would be expected to result in a tendency for plasma-cortisol levels to rise. The normal plasma-cortisol values that were in fact found imply a simultaneous reduction in cortisol production due to the negative feed-back control mechanism via the hypothalamus and pituitary as discussed by Yates and Urquhart (1962). A significantly lowered cortisol production rate, however, might reasonably be expected to be associated with a reduced urinary excretion of 17-OHCS metabolites. We found little evidence of this in wasted patients, though it should be noted that Cope and Black (1959) have shown that the correlation between 17-OHCS excretion and cortisol production is poor when the production rate is low. Indeed, our own observations on the relationship between urinary 17-OHCS and cortisol production rate indicate that as the latter falls the decrease in urinary $17-O H C S$ is less than would be predicted.

In contrast, the excretion of urinary $17-\mathrm{KS}$ was considerably reduced in malnutrition by comparison with the control subjects. This finding would give support to the hypothesis that adrenocortical secretion is in fact decreased in this condition. Direct determination of steroid production rates in chronically malnourished patients would presumably resolve this problem.

A hepatic effect does not explain the impaired urinary 17-KS and 17-OHCS response to prolonged maximal A.C.T.H. stimulation, which rather indicates a quantitative reduction of the adrenal cortical reserve. Malnutrition might well be expected to result in a relative deficiency of the precursor materials required for the complex enzyme systems involved in steroid synthesis (Van Dyke et al., 1960; Spiro and Ball, 1961). This evidently does not impair the immediate plasma response to an acute stress such as hypoglycaemia, probably because there is enough precursor material available to allow a short-term response.

Additional investigations, such as studies of cortisol binding, urinary steroid fractionation, and the direct determination of cortisol production, will be required to elucidate fully the mechanisms by which malnutrition affects adrenocortical function. It would appear, however, that the effects of malnutrition involve both the adrenal cortex and the liver.

\section{Summary}

The effects of ill-health and malnutrition on adrenocortical function have been studied. No significant difference was found in basal urinary excretion values of 17-ketosteroids and 17-hydroxycorticosteroids between healthy volunteers and con- valescent hospital patients. The patients, however, had a significantly poorer urinary steroid response to corticotrophin (A.C.T.H.). This finding deserves consideration in the selection of subjects for a control series.

Patients suffering from chronic wasting conditions showed abnormalities of adrenocortical function characterized by a low urinary excretion of 17-ketosteroids, an impaired urinary steroid response to A.C.T.H., and a delayed clearance of cortisol from the plasma. Despite these findings, urinary 17-hydroxycorticosteroid excretion and plasma-cortisol levels were normal, as was the response to acute hypoglycaemic stress.

It is suggested that the findings in wasted patients were largely due to the effects of malnutrition, since improvement of this aspect of their condition was associated with improvement in their test results. It was concluded that the effects of malnutrition may fall principally upon the enzyme systems involved in steroid metabolism, producing both a delay in steroid catabolism and a quantitative reduction in the response of the adrenal cortex to A.C.T.H.

We gratefully acknowledge the assistance of the University of London Computer Unit, and one of us (J. L.) gratefully acknowledges financial support from the Medical Research Council. We thank the Director-General of Medical Services for permission to publish data on Royal Air Force personnel.

\section{REFERENCES}

Albeaux-Fernet, M., Bugard, P., and Romani, J. D. (1957). f. clin. Endocr., 17, 519.

Appleby, J. I., Gibson, G., Norymberski, J. K., and Stubbs, R. D. (1955). Biochem. F., 60, 453 .

Birke, G., Diczfalusy, E., and Plantin, L. O. (1960). F. clin. Endocr., 20, 593.

Bliss, E. L., and Migeon, C. J. (1957). Ibid., 17, 766.

Brown, H., Willardson, D. G., Samuels, L. T., and Tyler, F. H. (1954). 7. clin. Invest., 33, 1524.

Christy, N. P., Longson, D., and Jailer, J. W. (1957). Amer. f. Med., 23, 910 .

Cope, C. L., and Black, E. G. (1959). Brit. med. F., 2, 1117.

Denneberg, T., and Skanse, B. (1958). Acta med. scand., 161, 477

Drekter, I. J., Heisler, A., Scism, G. R., Stern, S., Pearson, S., and McGavack, T. H. (1952). ₹. clin. Endocr., 12, 55.

Eik-Nes, K., Sandberg, A. A., Migeon, C. J., Tyler, F. H., and Samuels, L. T. (1955). Ibid., 15, 13.

Emanuel, R. W. (1956). Ibid., 16, 801.

Few, J. D. (1961). \%. Endocr., 22, 31.

Gallagher, T. F. (1957). Cancer Res., 17, 520.

Helmreich, M. L., Jenkins, D., and Swan, H. (1957). Surgery, 41, 895

Helmreich, M. L., Jenkins, D., and Swan, H. (1957) Uurquhart, J. (1960). Endocrinology, 67, 222.

Hume, D. M., Nelson, D. H., and Miller, D. W. (1956). Ann. Surg., $143,316$.

Huseby, R. A., Reed, F. C., and Smith, T. E. (1959). F. appl. Phys., 14, 31 .

James, V. H. T., and de Jong, M. (1961). 9. clin. Path., 14, 425.

James, Landon, J., and Wynn, V. (1962). f. Endocr., 25, 211.

Landau, R. L., Knowlton, K., Anderson, D., Brandt, M. B., and Kenyon, A. T. (1948). F. clin. Endocr., 8, 133.

Landon, J., Wynn, V., and James, V. H. T. (1963). Ұ. Endacr., 27, 183.

Mills, I. H. (1962). Brit. med. Bull., 18, 127.

Moor, P. de, Steeno, O., Raskin, M., and Hendrikx, A. (1960). Acta endocr. (Kbk.), 33, 297.

Nabarro, J. D. N. (1961). The Adrenal Cortex, edited by G. K. McGowan and M. Sandler, p. 159. Pitman, London. - Moxham, A., and Walker, G. (1957). Brit. med. F., 2, 1018

Peterson, R. E. (1960). ₹. clin. Invest., 39, 320.

Prunty, F. T. G. (1956). Brit. med. F., 2, 615.

Sandberg, A. A., Eik-Nes, K., Migeon, C. J., and Samuels, L. T. (1956). F. clin. Endocr., 16, 1001 .

Shuster, S. (1957). Brit. F. Tuberc., 51, 279.

Shuster, S. (1957). Brit. f. Tuberc., 51,

Spiro, M. J., and Ball, E. G. (1961). ₹. biol. Chem., 236, 231.

Tomizawa, H. H., Narahara, H. T., Gibbons, C. A., and Williams, R. H. (1954). Proc. Soc. exp. Biol. (N.Y.), 85, 51.

Van Dyke, R. A., Wolf, G., and Johnson, B. C. (1960). Biochem. biophys., Res. Commun., 3, 123.

Yates, F. E., and Urquhart, J. (1962). Physiol. Rev., 42, 359. 